\title{
Gambaran Balance Cairan pada Anak Diare setelah Diberikan Pemenuhan Kebutuhan Cairan di Rumah Sakit Kaliwates Jember
}

\section{(The Feature of Fluid Balance in Children with Diarrhea after Fluids Fulfillment at Kaliwates Hospital in Jember)}

\author{
Prasetyo Adi Prabowo, Lantin Sulistyorini, Peni Perdani Juliningrum \\ Fakultas Keperawatan Universitas Jember \\ Jl. Kalimantan No. 37 Kampus Tegal Boto Jember Telp./Fax. (0331) 323450 \\ e-mail korespondensi: lantin.sulistyorini@gmail.com
}

\begin{abstract}
Diarrhea is a global event in various countries, including in many developing countries. Management of diarrhea is to use fluid rehydration. Other diarrhea management can be used with supplements, using Oral Rehydration Salt (ORS), using medication from the doctor, and drinking lots of water to replace lost fluids. This study aims to determine how to describe the fluid balance in children with diarrhea after being given the fulfillment of fluid needs in the hospital. The research was conducted at Kaliwates Hospital in Jember, with the research time used by researchers was one month. The sample of this study was thirtytwo children of diarrhea patients with mild, moderate, severe dehydration. Data collection was carried out for three days while the child is hospitalized. The result of this study was obtained from total sampling. It was obtained that the fluid balance in diarrhea children did not all turn into balance. There was excess fluid, and they still experienced dehydration. From the research data, it was found that most of the experience of extra fluid status. The study concludes that after rehydration, children have an increasing fluid status. Fulfillment of fluids in children with diarrhea aims to reduce the risk of decreased fluid and maintain body fluids when they lose fluid through liquid feces. Fluid balance makes people's body became immune to the disease.
\end{abstract}

Keywords: Children, Diarrhea, Dehydration, Fluid Balance

\begin{abstract}
Abstrak
Diare merupakaan kejadian global dibeberapa negara, termasuk beberapa negara berkembang. Manajemen diare adalah dengan rehidrasi cairan. Beberapa manajemen diare dapat menggunakan suplement, rehidrasi cairan garam oral, menggunakan obat medis dari dokter dan meminum banyak air untuk mengganti cairan yang hilang. Penelitian ini bertujuan untuk mendeskripsikan balance cairan pada anak diare setelah diberikan pemenuhan kebutuhan cairan di rumah sakit. Penelitian dilakukan di rumah sakit Kaliwates Jember dengan jangka waktu penelitian selama satu bulan. Sampel pada penelitian ini menggunakan 32 anak diare dengan dehidrasi ringan, sedang, dan berat. Data penelitian diambil selama tiga hari selama anak dirawat di rumah sakit. Hasil dari penelitian ini didapatkan anak mengalami kenaikan cairan dan kelebihan cairan. Kesimpulan dari penelitian ini adalah anak mengalami peningkatan cairan setelah diberikan rehidrasi. Rehidrasi cairan pada anak diare yang mengalami dehidrasi dapat membantu mengurangi kehilangan cairan dan membantu keseimbangan cairan dalam tubuh anak.
\end{abstract}

Kata Kunci : Anak-anak, Diare, Dehidrasi, Keseimbangan cairan

e-Journal Pustaka Kesehatan, vol. 8 (no.3), September 2020 


\section{Pendahuluan}

Penyakit diare merupakan kejadian global di berbagai negara, termasuk di banyak negara berkembang. Penyakit diare dapat disebabkan oleh banyak faktor, diantaranya adalah faktor lingkungan terutama pada masalah kebersihan lingkungan, faktor sosiodemografi yaitu pengaruh dari jenjang pendidikan orang tua serta umur anak, dan faktor perilaku yang merupakan faktor yang berpengaruh dalam penyebaran kuman pada seorang individu/anak [1]. Diare banyak terjadi pada usia 15 tahun, karena pada usia tersebut anak rentan tertular penyakit karena kekebalan tubuh yang masih dalam tahap perkembangan [2]. Pada anak usia balita masih dalam tahap perkembangan sistem motorik, sehingga anak akan lebih sering memegang benda-benda yang kotor ataupun bersih [3].

Manifestasi klinis yang biasanya muncul pada diare adalah respon anak yang mengalami defekasi dengan pengeluaran feses yang lembek dan cair serta disertai lender [4]. Menurut WHO (2017), menjelaskan bahwa ancaman yang paling bahaya dari diare adalah adanya dehidrasi pada penderitanya [5]. Dehidrasi menjadi berbahaya karena selama dehidrasi cairan seperti air dan elektrolit dalam tubuh (natrium, klorida, kalium, dan bikarbonat) akan hilang melalui tinja cair, keringat, urin, dan pernapasan. Dampak dari dehidrasi adalah tubuh akan kehilangan cairan yang dibutuhkan oleh tubuh, seperti cairan yang dibutuhkan oleh sistem pencernaan untuk mencerna makanan, hilangnya cairan juga akan menyebabkan transportasi nutrisi sel-sel tubuh terganggu. Kehilangan cairan akibat dehidrasi dapat menimbulkan syok hipovolemik, yaitu kondisi ketika sistem kardiovaskuler gagal melakukan perfusi jaringan dengan adekuat, dan akibatnya jika tida segera ditangani bisa terjadi kematian [6]. Penatalaksanaan diare menjadi hal penting untuk dilakukan demi mengurangi terjadinya dehidrasi yang lebih parah. Upaya dari penatalaksaan ini dapat menurunkan angka dari kematian diare pada anak bila melakukan penanganannya secara cepat dan tepat [7]. Menurut WHO (2017), mengatakan bahwa penatalaksanaan atau intervensi dari diare dengan dehidrasi adalah dengan menambah asupan air minum, termasuk air minum yang aman [5]. Pada anak yang mengalami diare, maka jumlah output akan lebih banyak daripada intakenya. Pemberian manajemen cairan tersebut berfungsi untuk mempertahankan serta mengembalikan keseimbangan antara cairan yang masuk dan keluar [8].
Pemantauan dalam pemberian
kebutuhan cairan diperlukan untuk mendeteksi tanda-tanda kelebihan volume cairan, selain itu memantau keseimbangan cairan pada pasien anak dengan diare bertujuan untuk mengukur masukan dan keluaran cairan setiap harinya [6]. Berdasarkan hasil penelitian sebelumnya, penelitian akan dilakukan di Rumah Sakit Kaliwates Jember dengan mengambil anak usia balita sebagai responden yang memiliki diare dengan dehidrasi ringan, sedang, dan berat.

\section{Metode Penelitian}

Metode penelitian ini menggunakan desain penelitian deskriptif analitik. Metode ini menggambarkan data dari populasi anak yang menderita diare dengan kategori derajat dehidras ringan, sedang, dan berat yang dirawat di Rumah Sakit Kaliwates Jember. Populasi dari penelitian menggunakan usia balita yaitu usia 1 sampai dengan 5 tahun dengan kategori derajat dehidrasi ringan, sedang, dan berat. Kriteria inklusinya adalah pasien anak dengan diagnosa medis diare, memiliki usia 1-5 tahun, dan mengalami dehidrasi dengan kategori ringan, sedang, dan berat. Kriteria ekslusinya yaitu pasien yang menolak menjadi partisipan penelitian. Penelitian dilakukan selama bulan November 2019 sampai dengan Desember 2019. Pengumpulan data dilakukan pada Februari 2020.

Alat pengumpulan data menggunakan lembar observasi yang dibuat oleh peneliti untuk mengobservasi kebutuhan cairan yang masuk dan keluar pada anak tersebut selama 24 jam. Teknik pengumpulan data dimulai dari permohonan izin penelitian dari Fakultas Keperawatan Jember, kemudian kepada bagian Lembaga Penelitian dan Pengabdian Masyarakat Universitas Jember, serta izin dari pihak Rumah Sakit Kaliwates Jember. Peneliti melakukan pengambilan data dengan mengobservasi setiap anak dengan diare yang dirawat di Rumah Sakit Kaliwates Jember selama tiga hari, dan kemudian melakukan penghitungan total selama tiga hari untuk mendapatkan hasil input dan output cairan. Data disajikan dalam bentuk skala ordinal. Analisis data menggunakan SPSS 20. 


\section{Hasil Penelitian}

Penelitian ini dilakukan selama kurun waktu November 2019 sampai dengan Desember 2019. Pada Tabel. 1 merupakan karakteristik responden, dimana menunjukkan bahwa usia rata-rata pasien anak diare adalah usia balita yaitu 1 sampai dengan 5 tahun.

Tabel 1 Karakteristik Usia Responden

\begin{tabular}{|c|c|c|c|c|}
\hline No & $\begin{array}{c}\text { Usia } \\
\text { (tahun) }\end{array}$ & $\begin{array}{c}\text { Klasifika- } \\
\text { si }\end{array}$ & $\begin{array}{c}\text { Frekuen } \\
\text { si }\end{array}$ & $\begin{array}{c}\text { Persentase } \\
(\%)\end{array}$ \\
\hline 1 & 1 & Infant & 14 & 43,8 \\
\hline 2 & 2 & Toddler & 6 & 18,8 \\
\hline 3 & 3 & Toddler & 8 & 25 \\
\hline 4 & 4 & Preschool & 2 & 6,3 \\
\hline 5 & 5 & Preschool & 2 & 6,3 \\
\hline Total & & & 32 & 100 \\
\hline
\end{tabular}

Berdasarkan Tabel 2, didapatkan hasil dari kategori jenis kelamin pada pasien yang dirawat dirumah sakit Kaliwates Jember, dimana pasien diare mayoritas adalah laki-laki.

Tabel 2 Karakteristik Jenis Kelamin Responden

\begin{tabular}{cccc}
\hline No & $\begin{array}{c}\text { Jenis } \\
\text { Kelamin }\end{array}$ & Frekuensi & $\begin{array}{c}\text { Persentase } \\
\text { (\%) }\end{array}$ \\
\hline Laki-laki & 18 & 56,3 \\
Perempuan & 14 & 43,7 \\
\hline Total & $\mathbf{3 2}$ & $\mathbf{1 0 0}$ \\
\hline
\end{tabular}

(Sumber; Peneliti, Januari 2020)

Pada hasil dari penelitian ini didapatkan data penghitungan input dan output cairan anak yang mengalami dehidrasi setelah diberikan pemenuhan kebutuhan cairan; yaitu merupakan total dari penghitungan intake dan output yang didapatkan anak selama 24 jam menerima implementasi selama dirawat di rumah sakit.

\section{Pembahasan}

Penelitian ini menunjukkan gambaran balance cairan dari anak diare yang dirawat di rumah sakit Kaliwates Jember yang memiliki dehidrasi dengan derajat ringan, sedang, dan berat. Pada Tabel.1 menunjukkan bahwa usia rata-rata pasien anak diare adalah usia balita yaitu 1 sampai dengan 5 tahun, sedangkan pada Tabel. 2 menunjukkan bahwa diare hamper menjangkit lakilaki maupun wanita. Pada responden yang berada di rumah sakit kaliwates terdapat beberapa anak yang mengalami kelebihan cairan saat diare. Hal tersebut disebabkan oleh malaborpsi cairan yang menyebabkan proses absorpsi dan reabsorpsi cairan tidak seimbang dengan gejala berupa sakit di perut [9]. Pada anak yang dirawat di rumah sakit dapat memungkinkan terjadinya stress hospitalisasi dimana anak dapat menjadi gelisah akibat dari lingkungan baru karena anak harus dirawat inap selama di rumah sakit. Kondisi nutrisi dari pasien anak yang menderita diare di rumah sakit kaliwates dikategorikan dalam dua kategori yaitu status nutrisi kurang dan lebih. Pada anak dengan kondisi nutrisi kurang didapatkan bahwa asupan gizi yaitu makanan, minum, serta ASI tambahan tidak memenuhi kebutuhan dari kebutuhan nutrisi harian tersebut, sedangkan pada kondisi nutrisi yang lebih anak menerima asupan nutrisi yang lebih terutama pada minum dan ASI [10]. Kondisi pada pasien anak dengan diare sebelum diberikan intervensi manajemen cairan dan rehidrasi yaitu anak mengalami kekurangan dan kelebihan cairan. Penyebab dari kekurangan cairan pada pasien anak diare di rumah sakit

Kaliwates adalah didapatkan data dari hasil pengkajian pasien baru yaitu anak mengalami muntah dan diare berkali-kali sebelum dibawa ke rumah sakit serta anak tidak mau untuk makan dan minum. Pemberian rehidrasi selama 6 jam pada kondisi dehidrasi berat dan pemberian selama 3-4 jam untuk kondisi dehidrasi ringan dan sedang.Kondisi anak diare di Rumah Sakit Kaliwates setelah diberikan intervensi cairan mengalami perubahan dari kekurangan cairan menjadi seimbang dan pada beberapa anak mengalami kelebihan cairan. Hal ini disebabkan karena anak diberikan intervensi cairan yaitu berupa rehidrasi melalui infus, obat dari tenaga medis, serta didukung dengan pemberian makan oleh keluarga sebagai pengganti nutrisi dan cairan yang hilang akibat diare dan muntah [11].

Implikasi keperawatan dari penelitian ini adalah berkaitan dengan pemenuhan kebutuhan cairan pada anak dengan diare yang dapat mengurangi resiko penurunan cairan dan mempertahankan cairan tubuh ketika anak kehilangan cairan melalui feses yang cair. Upaya penanganan dini terhadap gejala anak yang menunjukkan tanda-tanda diare merupakan langkah preventif dalam 
mencegah terjadinya dehidrasi yang berat pada anak. Pemberian ORS dapat dilakukan untuk mencegah terjadinya kehilangan cairan akibat diare. Ketika anak mengalami dehidrasi berat keluarga dapat merujuk anak ke rumah sakit untuk mendapatkan penanganan rehidrasi dari tenaga medis.

\section{Simpulan dan Saran}

Gambaran dari balance cairan anak diare dengan dehidrasi di rumah sakit Kaliwates Jember setelah diberikan pemenuhan kebutuhan cairan, mengalami peningkatan balance cairan dan mengalamai kenaikan maintenance yang baik.

Diharapkan penelitian ini dapat menjadi gambaran data dalam mengimplementasikan pemenuhan kebutuhan cairan di rumah Sakit Kaliwawtes Jember, dan dapat menjadi data baru selama 2019 terhadap pasien anak diare yang dirawat di rumah sakit Kaliwates Jember.

\section{Ucapan Terima Kasih}

Penulis mengucapkan terima kasih kepada Fakultas Keperawatan Universitas Jember sebagai tempat studi dan bimbingan penelitian Kelompok Riset (Keris) Percasa, serta kepada Rumah Sakit Kaliwates Jember yang telah mengizinkan dan berpartisipasi dalam penelitian ini.

\section{Daftar Pustaka}

[1]. Utami N, \& Luthfiana N. Faktor-Faktor yang Memengaruhi Kejadian Diare pada Anak. Majority, 2016. 5(4):101-106.

[2]. Juvitha DC, Nurbaiti L, Suryani D. (2019). Gambaran Kasus Diare Akut pada Anak di Bawah 5 Tahun yang dirawat Inap di RSU Provinsi NTB tahun 2015. Jurnal Kedokteran Unram 2019. 8 (1): 13-6.
[3]. Poka H, \& Duke T. Clinical management of diarrhoea in children. Papua and New Guinea Medical Journal 2013. 56: 156161.

[4]. Herdman $T$. NANDA International Diagnosis Keperawatan. EGC.Jakarta. 2015.

[5]. World Health Organization. 2017.Diarrhoeal Disease. https://www.who.int/en/news-room/factsheets/detail/diarrhoeal-disease. [Diakses pada 10 Juni 2019].

[6]. Kusnanto. Modul Pembelajaran Pemenuhan Kebutuhan Cairan \& Elektrolit. Surabaya: Fakultas Keperawatan Universitas Airlangga. 2016.

[7]. Wardani S, \& Purborini N. Penggunaan Antibiotik Dan Antidiare Pada Anak Diare Akut Di Rumah Sakit. Journal of Holistic Nursing Science, 2018. 5(1): 43-48.

https://doi.org/10.31603/nursing.v5i1.18 78 [Diakses pada 10 Juni 2019]

[8]. Potter and Perry. Fundamental Keperawatan Edisi 4. Vol 1 \& 2. EGC. Jakarta. 2012.

[9]. Kyle T. \& Carman S. Buku Ajar Keperawatan Pediatric Vol 3, Edisi 2. EGC. Jakarta. 2016.

[10]. Whyte LA, \& Jenkins HR. Pathophysiology of diarrhoea. Paediatrics and Child Health (United Kingdom), 2012. 22(10): 443-447. https://doi.org/10.1016/j.paed.2012.05.0 06 [Diakses pada 9 Juni 2019].

[11]. Trevor RP, Koyfman A, Runyon MS. Emergency centre management of paediatric diarrhoea: An overview. African Journal of Emergency Medicine. $2013 . \quad 3$ : 75-82. doi: http://dx.doi.org/10.1016/j.afjem.2012.06 .004 [diakses pada 22 Juni 2019]. 
Prabowo, et al, Gambaran Balance Cairan pada Anak Diare setelah Diberikan Pemenuhan ......

Tabel 3. Distribusi Balance Cairan Responden Sesudah Dilakukan Intervensi Cairan (Sumber; Peneliti, Januari 2020)

\begin{tabular}{|c|c|c|c|c|c|c|c|}
\hline No & $\begin{array}{l}\text { Usia } \\
\text { (tahun)! }\end{array}$ & $\begin{array}{c}\text { Berat } \\
\text { Jadan }(\mathrm{kg})\end{array}$ & $\begin{array}{c}\text { Derajat } \\
\text { dehidrasi }\end{array}$ & $\begin{array}{l}\text { Kebutuhan } \\
\text { cairan (cc) }\end{array}$ & $\begin{array}{l}\text { Balance cairan } \\
\text { sebelum } \\
\text { implementasi } \\
\text { (cc) } \\
\end{array}$ & Implementasi (cc) & $\begin{array}{c}\text { Balance cairan } \\
\text { sesudah } \\
\text { implementasi } \\
\text { (cc) } \\
\end{array}$ \\
\hline 1 & 1 & 9,6 & Ringan & 1764 & Kurang & $\begin{array}{c}\text { Input } 1337,8 \\
\text { Output } 2218,8\end{array}$ & Lebih \\
\hline 2 & 3 & 10 & Sedang & 1925 & Lebih & $\begin{array}{l}\text { Input } 2031 \\
\text { Ouput } 2020\end{array}$ & Lebih \\
\hline 3 & 2 & 8 & Ringan & 1470 & Lebih & $\begin{array}{l}\text { Input } 1916 \\
\text { Output } 1474\end{array}$ & Lebih \\
\hline 4 & 1 & 7 & Ringan & 1286,25 & Lebih & $\begin{array}{l}\text { Input } 2158 \\
\text { Output } 2503\end{array}$ & Lebih \\
\hline 5 & 3 & 11 & Ringan & 2021,25 & Kurang & $\begin{array}{l}\text { Input } 2440 \\
\text { Output } 2947\end{array}$ & Lebih \\
\hline 6 & 3 & 11 & Ringan & 2021,25 & Lebih & $\begin{array}{l}\text { Input } 2170 \\
\text { Output } 1972\end{array}$ & Lebih \\
\hline 7 & 2 & 9 & Ringan & 1603,75 & Lebih & $\begin{array}{l}\text { Input } 2574 \\
\text { Output } 2552\end{array}$ & Lebih \\
\hline 8 & 2 & 11 & Sedang & 2007,5 & Lebih & $\begin{array}{l}\text { Input } 2178 \\
\text { Output } 1458\end{array}$ & Lebih \\
\hline 9 & 5 & 18 & Ringan & 1391,25 & Lebih & $\begin{array}{l}\text { Onput } 3754 \\
\text { Output } 1750\end{array}$ & Lebih \\
\hline 10 & 1 & 7,8 & Sedang & 1501,5 & Kurang & $\begin{array}{l}\text { Input } 2751,8 \\
\text { Output } 2976,2\end{array}$ & Lebih \\
\hline 11 & 1 & 9,4 & Sedang & 1809,5 & Kurang & $\begin{array}{l}\text { Input } 1380,5 \\
\text { Output } 1797,6\end{array}$ & Seimbang \\
\hline 12 & 1 & 9 & Sedang & 1732,5 & Kurang & $\begin{array}{l}\text { Input } 2157 \\
\text { Output } 2861\end{array}$ & Lebih \\
\hline 13 & 1 & 6,5 & Sedang & 1251,25 & Lebih & $\begin{array}{c}\text { Input } 2133 \\
\text { Output } 1663,5\end{array}$ & Lebih \\
\hline 14 & 1 & 8,6 & Sedang & 1695,5 & Kurang & $\begin{array}{c}\text { Input } 1721 \\
\text { Output } 2199,4\end{array}$ & Lebih \\
\hline 15 & 1 & 7,5 & Sedang & 1443,75 & Kurang & $\begin{array}{c}\text { Input } 1504 \\
\text { Output } 2242,5\end{array}$ & Kurang \\
\hline 16 & 3 & 13 & Ringan & 1653,75 & Lebih & $\begin{array}{l}\text { Input } 3979 \\
\text { Output } 2650\end{array}$ & Lebih \\
\hline 17 & 2 & 11 & Ringan & 1863,75 & Lebih & $\begin{array}{l}\text { Input } 2868 \\
\text { Output } 2259\end{array}$ & Lebih \\
\hline 18 & 3 & 12 & Ringan & 1627,5 & Lebih & $\begin{array}{l}\text { Input } 4500 \\
\text { Output } 1824\end{array}$ & Lebih \\
\hline 19 & 5 & 11 & Ringan & 1863,75 & Lebih & $\begin{array}{l}\text { Input } 2838 \\
\text { Output } 1700\end{array}$ & Lebih \\
\hline 20 & 4 & 14,5 & Ringan & 1430,63 & Kurang & $\begin{array}{c}\text { Input } 2048,25 \\
\text { Output } 2227\end{array}$ & Kurang \\
\hline 21 & 1 & 7,8 & Ringan & 1443,25 & Lebih & $\begin{array}{l}\text { Input } 2992,4 \\
\text { Output } 1636,2\end{array}$ & Lebih \\
\hline 22 & 3 & 13 & Ringan & 1286,25 & Lebih & $\begin{array}{c}\text { Inpt } 2207 \\
\text { Output } 1851\end{array}$ & Lebih \\
\hline 23 & 3 & 15 & Sedang & 1837,5 & Kurang & $\begin{array}{l}\text { Input } 1623 \\
\text { Output } 2030\end{array}$ & Lebih \\
\hline 24 & 1 & 8,6 & Sedang & 1655,5 & Lebih & $\begin{array}{c}\text { Input } 1572,8 \\
\text { Output } 1374,4\end{array}$ & Lebih \\
\hline
\end{tabular}


Prabowo, et al, Gambaran Balance Cairan pada Anak Diare setelah Diberikan Pemenuhan ......

\begin{tabular}{|c|c|c|c|c|c|c|c|}
\hline 25 & 3 & 10 & Ringan & 1837,5 & Lebih & $\begin{array}{l}\text { Input } 2034,5 \\
\text { Output } 1770\end{array}$ & Lebih \\
\hline 26 & 1 & 9 & sedang & 1735,5 & Kurang & $\begin{array}{l}\text { Inout } 2572 \\
\text { Output } 3111\end{array}$ & Lebih \\
\hline 27 & 4 & 16 & Ringan & 1595 & Lebih & $\begin{array}{l}\text { Input } 2630 \\
\text { Output } 2091\end{array}$ & Lebih \\
\hline 28 & 1 & 8,3 & Ringan & 1525,13 & Lebih & $\begin{array}{c}\text { Input } 2370,9 \\
\text { Output } 1565,7\end{array}$ & Lebih \\
\hline 29 & 1 & 9 & Sedang & 1732,5 & Lebih & $\begin{array}{l}\text { Input } 3522 \\
\text { Output } 3261\end{array}$ & Lebih \\
\hline 30 & 1 & 10,5 & Sedang & 2021,25 & Kurang & $\begin{array}{c}\text { Input } 3232 \\
\text { Output } 4904,5\end{array}$ & Lebih \\
\hline 31 & 2 & 10 & Sedang & 1925 & Lebih & $\begin{array}{l}\text { Input } 3430 \\
\text { Output } 1880\end{array}$ & Lebih \\
\hline 32 & 1 & 12 & Sedang & 1265 & Lebih & $\begin{array}{l}\text { Input } 2302 \\
\text { Output } 1248\end{array}$ & Lebih \\
\hline
\end{tabular}

